\title{
MOTERŲ ŽINIOS APIE RIBOJAMUS KOSMETIKOS GAMINIŲ INGREDIENTUS NĖŠTUMO METU
}

\author{
Diana Barragan Ferrer, Jesus Manuel Barragan Ferrer, Žaneta Mickienė, Monika Bielinytė \\ Kauno kolegija, Medicinos fakultetas
}

Raktažodžiai: nėštumas, ribojami kosmetikos gaminių ingredientai, moterų žinios, kosmetikos gaminys.

\begin{abstract}
Santrauka
Moterys ne visada žino apie galimą žalingą kosmetikos gaminių ingredientų poveikị nèštumo metu. Kenksmingų komponentų poveikis gali pasireikšti naudojant didelį kosmetikos gaminių kiekị, nes viename produkte esančios ribojamos medžiagos, naudojamos leistinos koncentracijos, yra saugios vartotojui ir neturi įtakos nei motinai, nei vaisiui. Moterys nèštumo metu gali naudoti net keliasdešimt kosmetikos produktų, kurių kenksmingų medžiagų koncentracija sumuodamasi gali viršyti saugias ribas. Pastaraisiais metais dažniau kalbama apie kosmetikos ingredientų naudingumą ir veiksmingumą. Skatinama naudoti kuo daugiau ịvairių kosmetikos produktų, tačiau nutylima apie jų komponentų galimą žalingą poveikị něščiajai ir vaisiui. Tyrimo tikslas - atskleisti moterų žinias apie ribojamus kosmetikos gaminių ingredientus néštumo metu. Tyrimui atlikti buvo naudojama anketinè apklausa. Tyrimo rezultatai atskleidè, kad dauguma moterų nepakankamai žino apie kenksmingus kosmetikos gaminių ingredientus, tokius kaip konservantai, kvapiosios medžiagos, retinolis, UV filtrai, triklozanas, tirpikliai ir gyvulinès kilmès hormonai, kurie néštumo metu gali turèti įtakos moteriai ir vaisiui. . Dauguma respondenčių žinojo, kad kosmetikos gaminiuose gali būti ir sunkiųjų metalų, bet nežinojo, kokị neigiamą poveiki jie gali sukelti nèštumo metu.
\end{abstract}

\section{Ivadas}

Nèštumo metu, kai vyksta kūno dydžio ir formų pokyčiai, kai kurios něščiosios patiria vidinį diskomfortą ir, žiūrèdamos ị savo atvaizdą, jaučia nepasitenkinimą. Pasikeitusią išvaizdą bando koreguoti, naudodamos įvairiausius kosmetikos gaminius (mažiausiai per dieną naudoja apie 15 kosmetikos gaminių, įskaitant dekoratyvinę kosmetiką), taip viršydamos minimalią dienos koncentraciją, kuri turi įtakos žmogaus sveikatos būklei. Kai kurie tyrimai buvo atlikti JAV ir Kanadoje dèl kosmetikos vartojimo néštumo metu, tačiau nè viename iš jų nebuvo nagrinejjami ịpročių pokyčiai, tokie kaip vartojimo nutraukimas ar sumažinimas dèl nėštumo. Nebuvo įvertintas ir moterų kosmetikos vartojimo nèštumo metu rizikos suvokimas [1]. Kosmetikos gaminiuose esančios pavojingos medžiagos gali tiesiogiai prasiskverbti per epidermio barjerą į žmogaus dermą ir, patekusios ị sisteminę kraujotaką, pakenkti moterų vaisingumui ir reprodukcinei sistemai [1]. Šios cheminès medžiagos gali sutrikdyti mènesinių ciklą, sukelti nevaisingumą, savaiminị persileidimą [2], anemiją, inkstų nepakankamumą, neigiamai paveikti širdies ir kraujagyslių sistemas [3]. Mokslininkų atlikto tyrimo rezultatai parodè, kad cheminès medžiagos gali daryti neigiamą poveikị vaisiui: sulètinti organų vystymosi procesus, susilpninti imuninę sistemą, sutrikdyti hormonų gamybą, pažeisti centrinę nervų sistemą, kuri turi įtakos elgsenos sutrikimams ir neurologiniam vystymuisi [4-5]. Ftalatai bei parabenai yra cheminès medžiagos, kurios prasiskverbia per placentą, jungiančią motiną ir vaisių. Dèl to gali sutrikti normalus lytinis vystymasis ypač vyriškos lyties vaisiui (pvz.: hipospadija, kriptorchidizmas ir kt.) [6]. Kai kurie ftalatai turi endokrininę sistemą ardantị poveikị, kuris siejamas su vaisiaus augimo suletejimu, per ankstyvu gimimu, hormonų gamybos sutrikimu, nervų ir pažinimo raidos vaikystėje sutrikimu, hormoniniais sutrikimais brendimo laikotarpiu [5]. Vaikas ir motina, něštumo metu paveikti ftalatų, daugeliu atvejų patyré kasdienybeje būtinų motorinių - orientacinių funkcijų sutrikimų [7].

Sveikatos priežiūros specialistai neinformuoja moterų apie kosmetikos gaminių cheminių medžiagų riziką něščiajai ir vaisiui. Perinatalinès sveikatos specialistų (akušerių, šeimos gydytojų, vaistininku), kosmetologų parama ir patarimai yra būtini bet kokiai prevencijos ir informavimo strategijai, kuria siekiama apriboti kosmetikos gaminių vartojimą něštumo metu [1].

Tyrimo tikslas - atskleisti moterų žinias apie ribojamus kosmetikos gaminių ingredientus néštumo metu. 


\section{Tyrimo medžiaga ir metodai}

Tyrimui atlikti buvo taikoma kiekybinè strategija - anketiné apklausa. Tyrime dalyvavo 115 respondenčių. Atranka tikslinè apklausiamos moterys, kurios yra ar buvo něšcios. Respondentès tyrime dalyvavo savanoriškai. Joms buvo užtikrintas anonimiškumas ir konfidencialumas. Paaiškinta, kad gauti rezultatai bus naudojami tik apibendrinti.

\section{Tyrimo rezultatai}

Apklausoje iš viso dalyvavo 115 moterų. Aktyviausiai savo žiniomis apie ribojamus kosmetikos ingredientus néštumo metu dalinosi 18-23(27 proc. apklaustujų) ir 30-35(26 proc.) metų moterys. Mažesnè dalis atsakiusiujų buvo 24-29(13 proc.) ir 45 ir daugiau (14 proc.) metų amžiaus grupèse. Iš visų tyrime dalyvavusių moterų 26 proc. sudarè nëščiosios. Néččiosios, manančios, kad kosmetikos cheminès medžiagos yra pavojingos, elgiasi atsargiau ir mažiau naudoja kosmetikos gaminių, jausdamos didelę atsakomybę už naujos gyvybès sveikatą, nei tos néščiosios, kurios teigia, kad kosmetikoje nèra tokių ingredientų, kurie galètų pakenkti tiek moteriai, tiek vaisiui [1]. Tai patvirtino ir šiame tyrime atlikta apklausa, kurios rezultatai parodè, kad didžioji dalis ( 80 proc.) nèštumo metu naudoja (naudojo) 1-10 kosmetikos priemonių per dieną. Mažiau respondenčių (14 proc.) atsakè, kad per dieną naudoja 15-20 priemonių. 20 ir daugiau kosmetikos gaminių naudoja 6 proc. apklaustujų. Nëštumo metu, kai vyksta kūno dydžio ir formų pokyčiai (strijos, celiulitas ir kt.), kai kurios něščiosios patiria vidinị diskomfortą ir žiūrèdamos ị savo atvaizdą jaučia nepasitenkinimą. Paklaustos, ar renkasi specialiai skirtą kosmetiką néščiosioms, mažiau nei pusė néščiujų (40 proc.) atsakè teigiamai. C. Marie ir kt. (2016) atlikto tyrimo rezultatai parode, kad kosmetologai moterims neteikia informacijos dèl kosmetikos vartojimo néštumo metu ar apie galimus ịpročių pokyčius, neinformuoja apie kosmetikos gaminių cheminių medžiagų riziką néščiajai ir vaisiui [1]. Tai patvirtino ir šios apklaustos respondentès, kurių didžioji dalis (70 proc.) atsakè, kad kosmetologas nesuteikia reikiamos informacijos ir nepaaiškina, kokius produktus saugu naudoti nèštumo periodu. Perinatalinę priežiūrą teikiančių specialistų, vaistininkų, kosmetologų ir kosmetikos priemonių konsultantų parama ir patarimai būtini bet kokiai prevencijos ir informavimo strategijai, kuria siekiama apriboti kosmetikos gaminių vartojimą [1]. Tyrimo rezultatai parode, kad 77,4 proc. apklaustujų perkant kosmetikos gaminius, kosmetologas, vaistininkas ar kosmetikos priemonių konsultantas neįspejo apie ingredientus, kurie gali sukelti neigiamą poveikị sveikatai. Galima daryti prielaidą, kad dauguma kosmetologų, vaistininkų ar kosmetikos priemonių konsultantų neturi žinių arba nėra motyvuoti teikti informacijos klientams apie chemines medžiagas, kurios gali sukelti neigiamą poveikị sveikatai.

Mokslinejje literatūroje teigiama, kad konservantai ir kvapiosios medžiagos ypač pavojingos néštumo metu. Šie ingredientai, esantys kosmetikos gaminiuose, gali pereiti per placentą, jungiančią něščiają ir vaisių, sukel-

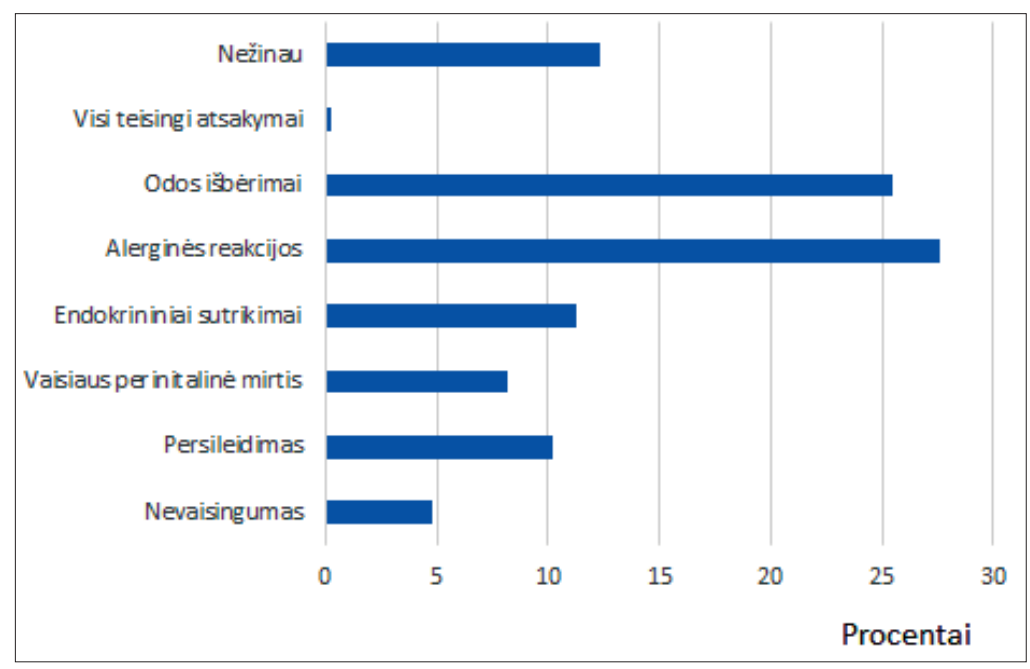

1 pav. Respondenčių žinios apie kosmetikos gaminiuose esančių parabenų, formaldehidų (konservantų) ir ftalatų (kvapiųjų medžiagų) neigiamą poveikį néštumo metu $(\mathrm{N}=115)$

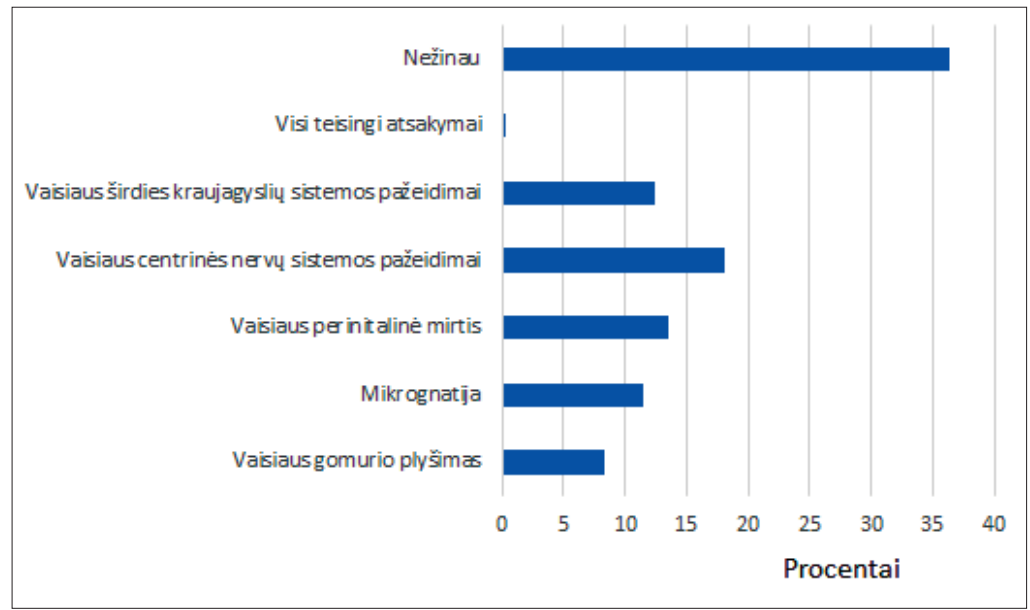

2 pav. Respondenčių žinios apie kosmetikoje esančio retinolio neigiamą poveikị néštumo metu $(\mathrm{N}=115)$ 
dami riziką vaisiaus sveikatai [8], todèl apklausos metu buvo siekiama atskleisti moterų žinias apie šių ingredientų sukeliamą neigiamą poveikį. Siekiant sužinoti, ar moterys žino pakankamai, buvo galimybė pažymèti kelis galimus atsakymų variantus. Visi pasirinkimai buvo teisingi, tačiau vienas pasirenkamas variantas buvo - nežinau. Ši atsakymą pasirinko 12,3 proc. apklaustujjų. Didžioji dalis apklaustujjų pažymėjo, kad konservantai ir kvapiosios medžiagos gali sukelti alergines reakcijas (27,6 proc.) ir odos išbėrimus (25,6 proc.). Galima teigti, kad didžioji dalis moterų žino tik esminę informaciją, kuri dažnai girdima žiniasklaidoje (1 pav.).

V. Brown ir kt. (2014) atlikto tyrimo rezultatai parodè, kad kosmetikos gaminiuose esantys retinoidai yra teratogeniški ir didelè dozė gali pakenkti vaisiui [9]. Respondentėms buvo pateiktas klausimas, ar žino, kokị neigiamą poveikị kosmetikos gaminiuose esantis retinolis gali sukelti nėštumo metu. Sudaryta galimybė pažymèti kelis galimus atsakymų variantus. Visi pasirinkimai buvo teisingi, tačiau didžioji dalis atsakiusiujų pažymejjo, kad nežino ( 36,3 proc.), kitos ( 18,1 proc.) teigè, kad retinolis gali pažeisti vaisiaus centrinę nervų sistemą (2 pav.).

UV filtrai gali toksiškai veikti reprodukcinę sistemą, sukelti fototoksiškumą ir genotoksiškumą [10]. Respondentems buvo pateiktas klausimas apie kosmetikos gaminiuose esančių UV filtrų neigiamą poveikị

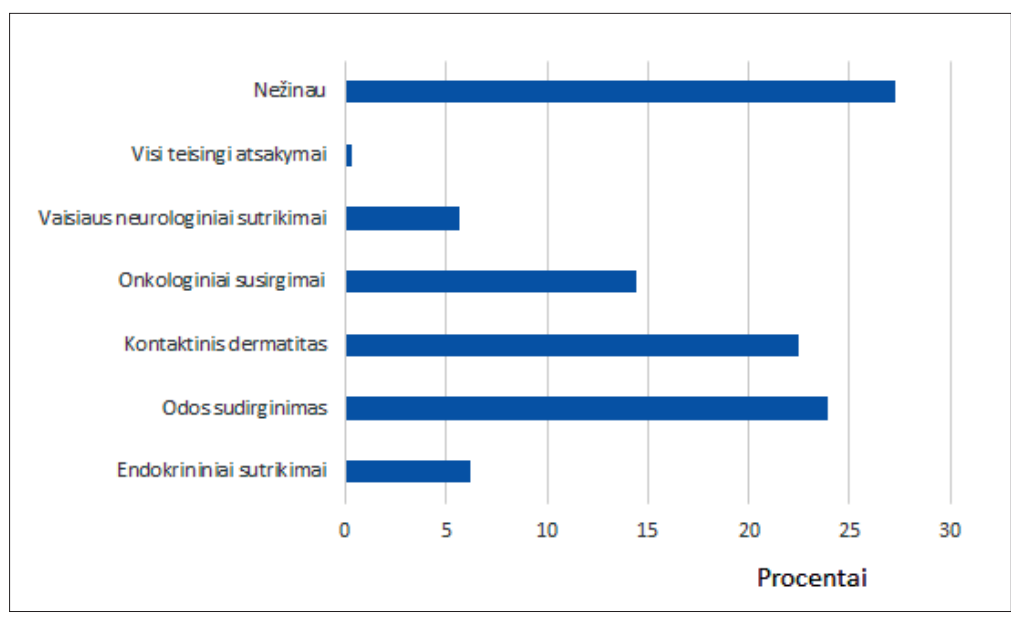

3 pav. Respondenčių žinios apie kosmetikos gaminio sudetyje esančių ultravioletinių (UV) filtrų neigiamą poveikị nèštumo metu $(\mathrm{N}=115)$

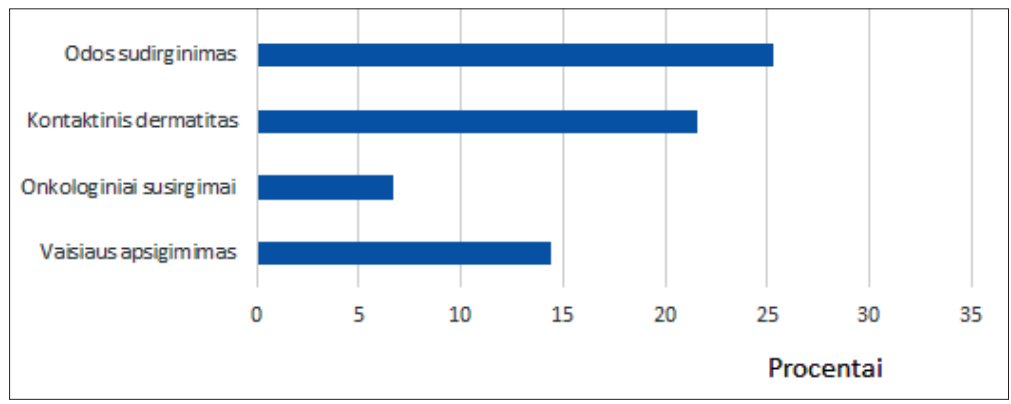

4 pav. Respondenčių žinios apie kosmetikos gaminiuose esančių tirpiklių (1,4dioksano ir alkoholio) neigiamą poveikị néščiajai ir vaisiui $(\mathrm{N}=115)$
(3 pav.). Dalis (27,3 proc.) apklaustujų pažymèjo, kad nežino, kokią neigiamą įtaką turi UV filtrai. Tik maža dalis moterų pažymèjo, kad UV filtrai gali sukelti endokrininius $(6,2$ proc.) ir neurologinius (5,7 proc.) sutrikimus. Apibendrinant, galima teigti, kad didžioji dalis moterų turi nepakankamai žinių apie UV filtrų sukeliamą neigiamą poveikị, o mažesnè dalis respondenčių žino tik tokią informaciją, kuri pateikiama reklamose, žiniasklaidoje.

Moterų buvo klausiama apie tirpiklių (1,4-dioksanas ir alkoholis) neigiamą poveikị něštumo metu (4 pav.). Dauguma apklaustujų teige, kad nežino (32 proc.). Dalis respondenčių atsakè, kad tirpikliai gali sukelti odos sudirgimą (25,3 proc.) ir kontaktinị dermatitą (21,6 proc.). Moksliniais tyrimais ịrodyta, kad etanolio vartojimas siejamas su odos dirginimu ar kontaktiniu dermatitu, ypač nėščiosioms, turinčioms aldehido dehidrogenazès (ALDH) trūkumą [1]. Ir tik maža dalis atsakiusiujjų pažymèjo, kad tirpikliai gali sukelti onkologinius susirgimus (6,7 proc.). Literatūros duomenimis, 1,4-dioksanas něščiajai gali sukelti ar paskatinti věžinių susirgimų vystymąsi [1].

Paklausus moteru, ar joms trūksta informacijos apie kosmetikos gaminiuose esančių ingredientų žalą néščiosioms, 96,5 proc. atsakè „Taip“. Beveik visos norètu gauti daugiau informacijos apie kosmetikos gaminio sudetyje esančias pavojingas (ribojamas) medžiagas iš specialistų, pas kuriuos lankosi néštumo metu, ar kosmetikos konsultanto.

Apibendrinus šio tyrimo rezultatus, galima teigti, kad apie kosmetikos ingredientų žalą néštumo metu kalbama per mažai ir moterims trūksta informacijos iš specialistų, pas kuriuos jos lankosi nèštumo metu.

\section{Išvados}

1. Ingredientai, esantys kosmetikos produktuose, gali tureti ịtakos moters ir vaisiaus sveikatai. Gaminant kosmetikos gaminius, laikomasi griežtų reikalavimų, tačiau naudojant priemones su ribojamais ingredientais ilgą laiką, jie kaupiasi organizme, motinos piene, cheminès medžiagos patenka vaisiui. Šie ingredientai gali lemti nëščiosios persileidimą, priešlaikini gimdymą, mažą kūdikio gimimo svorị, slopinti neurologini, plaučiu ir trachẻjos 
vystymąsi, sukelti įvairius apsigimimus: galūnių deformaciją, gomurio skeltumą, ausų ir akių ydas.

2. Gauti tyrimo rezultatai atskleidè, kad didžioji dalis respondenčių žinojo, jog kosmetikos gaminio sudetyje esantys ingredientai (konservantai, kvapiosios medžiagos, retinolis, UV filtrai, triklozanas, tirpikliai ir gyvulinès kilmès hormonas - placenta) gali turèti ittakos moters ir vaisiaus sveikatai něštumo metu, tačiau joms trūksta žinių apie šių medžiagų neigiamą poveikị něščiajai ir vaisiui.

\section{Literatūra}

1. Marie C, Cabut S, Venditelli F, Rochat M. Changes in Cosmetics Use during Pregnancy and Risk Perception by Women. Int J Environ Res Public Health 2016;13(4):383.

https://doi.org/10.3390/ijerph13040383

2. Duong A, Steinmaus C, McHale CM, Vaughan CP, Zhang L. Reproductive and developmental toxicity of formaldehyde: A systematic review. Mutation Research/Reviews in Mutation Research 2011;728(3):118-138.

https://doi.org/10.1016/j.mrrev.2011.07.003

3. Chen KL, Jiang SJ, Chen YL. Determining lead, cadmium and mercury in cosmetics using sweeping via dynamic chelation by capillary electrophoresis. Anal Bioanal Chem 2016;409: 2461-2469.

https://doi.org/10.1007/s00216-017-0193-1

4. Dickenson A, Woodruff J, Stotland E, Dobraca D, Das R. Elevated mercury levels in pregnant woman linked to skin cream from Mexico. Case report 2013;209(2).

https://doi.org/10.1016/j.ajog.2013.05.030

5. Marie C, Vendittelli F, Sauvant-Rochat MP. Obstetrical outcomes and biomarkers to assess exposure to phthalates: A review. Environment International 2015;83:116-136.

https://doi.org/10.1016/j.envint.2015.06.003

6. Cock D, Quaak I, Sugeng EJ, Legler J, Bor V. Linking EDCs in maternal Nutrition to Child health (LINC study) - Protocol for prospective cohort to study early life exposure to environmental chemicals and child health. BMC Public Health 2016;16:147. https://doi.org/10.1186/s12889-016-2820-8

7. Ejaredar M, Nyanza EC, Eycke TK, \& Dewey D. Phthalate exposure and childrens neurodevelopment: A systematic review. Environmental Research 2015;142:51-60.

https://doi.org/10.1016/j.envres.2015.06.014

8. Kolatorova L, Vitku J, Hampl R, Adamcova K, Skodova T, Simkova M, Parizek A, Starka L, Duskova M. Exposure to bisphenols and parabens during pregnancy and relations to steroid changes. Environmental Research 2018;163:115-122. https://doi.org/10.1016/j.envres.2018.01.031

9. Brown VJ. Metals in Lip Products - A Cause for Concern? Environ Health Perspect 2013; 121(6).

https://doi.org/10.1289/ehp.121-a196

10. Sung CR, Kim KB, Lee JY, Lee BM, Kwack SJ. Risk Assessment of Ethylhexyl Dimethyl PABA in Cosmetics. Toxicological Research 2019;35(2):131-136.

https://doi.org/10.5487/TR.2019.35.2.131

\section{WOMEN'S KNOWLEDGE ON RESTRICTED COSMETIC INGREDIENTS DURING PREGNANCY D. Barragan Ferrer, J.M. Barragan Ferrer, Ž. Mickienė, M. Bielinytė}

Key words: pregnancy, restricted ingredients in cosmetic products, women's knowledge, cosmetic product

Summary

Women are not always aware of the detrimental effects of chemical ingredients in cosmetics products during their pregnancy. When pregnant women are aware that a single product used contains acceptable concentrations to be safe, they are unfamiliar with the danger of the exposure of harmful components. This can occur when large quantities of cosmetic products are used simultaneously, and the concentrations of harmful substances can exceed the safe limits. This danger has brought attention to the importance of the usefulness and effectiveness of cosmetic ingredients. It is therefore important to find out the level of understanding about the effects of restricted substances in cosmetic products on the pregnant woman and the fetus. The aim of this study was to reveal the level of understanding of the ingredients of restricted cosmetics during pregnancy. A questionnaire survey was used to conduct the study. The results of the study revealed that most of the women surveyed are not sufficiently aware of the harmful ingredients in cosmetics that can affect health during pregnancy to both her and her fetus. Ingredients such as preservatives, fragrances, retinol, UV filters, triclosan, solvents, and animal hormones. Also, most respondents already knew the existence of heavy metals in cosmetics but are unaware of the negative effects they can cause during pregnancy.

Correspondence to: diana.barragan.ferrer@go.kauko.lt

Gauta 2021-09-06 